\title{
Speech Therapy: an Alternative Approach for Attention Deficit Hyperactivity Disorder Treatment in Early Childhood
}

\author{
Ifdil Ifdil \\ Department of Guidance and Counseling \\ Faculty of Education, Universitas Negeri Padang \\ Padang, Indonesia \\ ifdil@fip.unp.ac.id \\ Lira Erwinda \\ Department of Guidance and Counseling \\ Faculty of Education, Universitas Negeri Padang \\ Padang, Indonesia \\ lira@konselor.org \\ Elfi Churnia \\ Indonesian Institute for Counseling, Education and Therapy \\ Padang, Indonesia \\ elfi@iicet.org \\ Nilma Zola \\ Indonesian Institute for Counseling, Education and Therapy \\ Padang, Indonesia \\ zola@iicet.org
}

\author{
Rima Pratiwi Fadli \\ Department of Guidance and Counseling \\ Faculty of Education, Universitas Negeri Padang \\ Padang, Indonesia \\ rima@konselor.org \\ Alfina Sari \\ Department of Guidance and Counseling \\ Faculty of Education, Universitas Negeri Padang \\ Padang, Indonesia \\ alfina@konselor.org \\ Refnadi Refnadi \\ Department of Guidance and Counseling \\ Faculty of Education, Universitas Negeri Padang \\ Padang, Indonesia \\ refnadi@gmail.com \\ Zadrian Ardi \\ Department of Guidance and Counseling \\ Faculty of Education, Universitas Negeri Padang \\ Padang, Indonesia \\ zadrian@fip.unp.ac.id
}

\begin{abstract}
Attention Deficit Hyperactive Disorder (ADHD) is a new issue in neuropsychiatric syndrome experienced on Childhood Student. These symptoms interfere in the development of cognitive, social, and early-childhood communication. The background to this idea is in communicating a child with ADHD tends to difficulty in talking, like cutting and interfering with other people's conversation, difficulty stringing words, talking too loudly, speaking inefficiently, and often misstep's cause commotion with other on kindergarten/playgroup student. Difficulty communicating children ADHD this can be handled through the treatment by speech therapy. Speech therapy is used for the provision of treatments that deal with language, speech and sound disorders that serve as the foundation for making diagnosis and treatment. The manuscript objective is to describe ADHD and how to treatment it with speech therapy is oriented to train and sharpen phonological awareness of early childhood in recognizing alphabet and words, especially in its use to communicate.
\end{abstract}

Keywords-ADHD; speechtherapy;earlychildhood

\section{INTRODUCTION}

Development at an early age is a very important stage of child development as it is known as the "golden age" period[1][2][3]. This period is a period that contributes for development of children in the future. This consideration makes the need to be met and overcome various developmental disorders experienced by children in this age. Some phenomena experienced by early childhood associated in its development become an important thing to note. The phenomenon is related to the phenomenon of ADHD (Attention Deficit Hyperactivity Disorder)[4][5]. Attention deficit / hyperactivity disorder (ADHD) is a neurodevelopmental disorder in children characterized by improper development of attention, hyperactivity, and / or impulsivity, along with extensive functional and pervasive damage[6][7]. Certainly, these conditionswill greatly affect the academic achievements, welfare, and social interactions of children[8][9]. ADHD disorders affect $3-5 \%$ of early children[10][11]. Symptoms of ADHD can be seen before age seven years[12], then after that age if not handled properly will settle as a teenager or adult[13]. It is estimated that ADHD patients will persist or carry ADHD disorders with an estimated $15-20 \%$ of adults. In addition, about $65 \%$ will 
experience residual symptoms during adulthood or sometimes gradually disappear[14].

According to the American Psychiatric Association, ADHD has a negative effect of $3 \%$ to $10 \%$ on early-childhood [15]. Furthermore, in several studies found an increase in cases of ADHD in children [16]. ADHD that occurs in children can be a nuisance with speech, language or both, these issues are a concern and speech problems are often simultaneous. Attention problems and language problems have the same symptoms [17]. Children with ADHD experience many problems related to language and communication. Examples are:[17]: (1) disturbing others while speaking, (2) having difficulty in composing words, (3) speaking too loudly, and (4) not speaking coherently. ADHD sufferers can also be distracted by their own thoughts. They may make unrelated comments or talk about things that do not fit the context[17]. The findings from the study also describe that ADHD phenomena are related to genetic factors, family and environmental education and eating habits[18]. The ADHD child if left untreated has the potential for greater impact, which is analogous to the form of "iceberg"[19]. Furthermore, according to Weisler, et al, that ADHD children potentially will experience it until adulthood[20].

Explicitly ADHD makes a child different from other children. However, ADHD is not a condition that has always been an obstacle, with appropriate treatment and therapy of children with ADHD can be cured[21][22][23]. That statement has relevance with a research from Amazine.com in Artanti's research found that some types of therapy that can be used to treat children with ADHD[24]: (1) Behavioral Therapy[25]; (2) Cognitive Therapy [15]; (3) Literary Therapy; (4) Speech Therapy and other's therapy. Based on the results from the study found that suitable therapy is used for handling difficulties communicating children ADHD speech therapy[26]. Speech therapy is used to treat children with impaired communication[8]. As for children who experience communication disorders are often detected by being late in speaking[17]. This is in line with Song's research, et al. that through the use of speech therapy can also help children who experience speech delay, communication disorder by following several therapy sessions[27].

Based on the above exposure can be concluded that the phenomenon of ADHD has the potential to affect the development during early childhood. Therefore, the handling of ADHD children needs to be done one of them through the use of treatment speech therapy. This paper will describe about ADHD, speech therapy and how handling difficulties communicate early childhood as one alternative approach.

\section{RESUlt AND DisCUSSION}

\section{ADHD (Attention Deficit Hyperactivity Disorder)}

Concentration and hyperactivity disorder often called Attention Deficit Hyperactive Disorder (ADHD) is a recent neuropsychiatric syndrome common in children, usually accompanied by restless or hyperactivity, unable to concentrate intention, impulsive and inhibiting or destructive behavior that can cause an imbalance of most of their lives's activities that can generally disrupt schooling and academic achievement [19][20]. Furthermore, according to Strine et al. explained that children with ADHD have a disturbed or damaged cognitive. And then, it can disrupt communication; especially interfere with the learning process. This is so because the learning process in the early-childhood class requires more abilities to communicate well with his friends and teachers[28][29]. Based on the above exposure, it can be concluded that children with ADHD have the potential to interfere in terms of development and impact on learning activities.

\section{Speech Therapy}

According to WHO, speech therapy is a set of procedures and behavioral techniques that were originally designed to improve vocalization and articulation such as stuttering[30][31]. The application of the concept then develops in the rehabilitation of individuals who experience aphasia and in the implementation of language development disorder[13].

And then, according to Sunanikspeech therapy or speech therapy is used to deal with children of early age who experience communication disorders [26]. That statement has relevance with Ahmann's opinion that speech therapy can be used to help children who have difficulty in speaking. Children who experience communication disorders are often detected by being late in speech [26]. The therapy trains younger children skillfully using encoding that is the ability to speak by hand and other organs and facial expressions [26]. Furthermore, the use of speech therapy in children is expected to increase knowledge about the various types and characters of the language and can evaluate how to speak.

As in the medical science speech therapy is often used to help patients who have difficulty speaking or communicating due to experience a particular disease, for example, patients who have a stroke [14]. Furthermore, in the field of education, especially education of early childhood requires speech therapy. As Nakai's research that in dealing with early childhood can be used speech therapy to overcome children who have one or several symptoms of ADHD [17]. This is supported by the results of Brunner's research, et al that the use of speech therapy is effective in dealing with the disruption of speech and communication experienced by children in an early age range [33].

Furthermore, in relation with the process of speech therapy, based on the results of research, Artanti explained that speech therapy can be done when giving instruction at the time of the instruction process [12]. The handling of children with ADHD who experience speech disorders is focused on improving speech and language. Speech and language are a different thing. It is this utterance that makes the voice of spoken language. There are four elements that make up speech such as articulation, phonology, sound and fluency[34].

First, articulation makes sound. Until about the age of 5 or 6 , it is common for children to leave sounds (not bananas), substitute sounds (dismiss, not Thursday) or experience problems in making certain sounds (inning instead of yellow). 
If their inability to make the sound continues, it could be a sign of an articulation problem.

Second, phonology is how language sounds are structured to make words. Children with phonological problems can consistently change the sound made in the throat because of the sound made at the front of the mouth.Third, sound is the tone, volume and quality of speech. Children who have trouble with sound may sound hoarse, breathing as they speak. They may be talking too loud for this situation. Fourth, fluency refers to the flow of speech. Children with smooth problems may stutter, stammer or pause in the "wrong" places as they speak.

As for the classification of communication disorders that can be handled through speech therapy is[9]: First, speech interruption (articulation) is one type of communication behavior disorder due to one or more causes associated with the function of observation (sensation and perception), neuromuscular function, the condition of talking organs, or the influence of the environment has difficulty to use the sounds of the language with correct. In this case, the error lies in the point of articulation or on the way of producing the sound of the language (manner of articulation). Difficulty speaking is usually marked by substitution, omission, distortion (unclear) and addition. Articulation development disorders include the failure to say a letter to several letters, often the omission or replacement of the letters to give the impression of how to speak like a child. It can also be an interruption in pitch, volume or sound quality [14].

Second, language disorder is o ne type of communication behavior disorder in which people with language disorders experience obstacles or of the process of (coding) and used of linguistic by the environment, so that patients experience barriers in development, receptive ability barriers, expressiveness barriers. This language disorder can occur as a result of lesions in the language centers in the cerebral context.

Third, sound disturbance is one type of communication characterized by the disturbance of the sound production process (fonation), this usually occurs due to the causes of organic or functional. It also affects the function of the larynx at the time of the phonation. Disturbance in the sound production process can be characterized by interference on several aspects, including: loudness, tone (pitch), and quality. Sound disturbance is broadly divided into two namely dysphonia and afonia: a) Dysphonia is a condition of communication disorder in the form of deviation or imperfection in the production of sound caused by organic or functional factors. These conditions include: (1) tone disorders, and (2) impaired quality. b) Afonian is a condition of communication disorder caused by loss of sound source or failure at all in producing sound.

Fourth, rhythm/rhythm disturbance is one type of communication behavior disorder characterized by the repetition sound or syllable and prolongation and blocking at the time of speech. The existence of repetition, extension and blocking causes the patient is unable to speak fluently. It generally occurs in connection with psychosocial disorders or due to other causes that interfere with the neuromotor function of speech organs. Rhythm disturbance/fluency is divided into 3 namely: 1) stutter, 2) cluttering, and 3) talkative.

Fourth, swallowing disorders (dysphagia) is a difficulty swallowing divided into 3 (three) phases namely the oral phase, pharyngeal phase and phase esophageal caused by pathological, psychogenic and neurological conditions. The causes of language development disorder are numerous and extensive, all disturbances ranging from auditory processes, impulse forwarding to the brain, muscles or sound-making organs.

Next, according Sunanik the factors that cause the occurrence of speech disorders is[9]: first, internal factors or biological factors include perceptual factors, cognition factors, genetic factors, prematurity. Second, external factors or environmental factors include parenting and verbal environments. The procedure of speech therapy work can be detailed as follows [9]: First assessment. Assessment is conducted to obtain preliminary data that must be reviewed and analyzed to make the next program. The assessment includes three methods: observation, tests, and examination result from other experts. Second, diagnosis and prognosis. The diagnosis is done to determine the problems or disorders experienced by early childhood, and predict if the problem or disorder is not addressed, then the childhood student has the potential to have a more serious problem than before.

Third, planning speech therapy. The planning of speech therapy consists of: a) the purpose and the program to be performed; b) planning of method, technique, frequency and duration; c) planning the use of the tools needed in therapy; d) required referral planning; e) evaluation planning. Fourth, implementation of speech therapy. The implementation of speech therapy is oriented to the planning that has been made before. The various methods, techniques and approximate therapeutic time up to the final stage are also adapted to the planning before the therapy begins. Fifth, evaluation. The evaluation is related to monitoring of counselee condition (in this case early child with ADHD / Attention Deficit Hiperactivity Disorder). The results of the evaluation that has been done will be used to create the next program. Sixth, reporting results. The reporting of results in the form of reporting activity is ranging from assessment to evaluation[36].

\section{CONCLUSION}

From the various references above can be concluded that for handling difficulties communicating children ADHD, speech therapy can be one alternative. This paper describes how ADHD, speech therapy and how both work. Based on the above exposure, it can be concluded that the use of speech therapy can handle symptoms of children with ADHD. This manuscript recommends the need for all workers working with ADHD such as social workers, kindergarten teachers, counselors, therapists and other psychotherapists must be understood and apply treatment using speech therapy.

\section{References}

[1] G. Eason, B. Noble, and I. N. Sneddon, "On certain integrals of Lipschitz-Hankel type involving products of Bessel functions," Philos. 
Trans. R. Soc. London A Math. Phys. Eng. Sci., vol. 247, no. 935, pp. 529-551, 1955.

[2] J. C. Maxwell, A treatise on electricity and magnetism, vol. 1. Clarendon press, 1881.

[3] I. S. Jacobs, "Fine particles, thin films and exchange anisotropy," Magnetism, pp. 271-350, 1963.

[4] K. Elissa, "Title of paper if known." unpublished, 2003.

[5] S. S. Lee, K. L. Humphreys, K. Flory, R. Liu, and K. Glass, "Prospective association of childhood attention-deficit/hyperactivity disorder (ADHD) and substance use and abuse/dependence: a metaanalytic review," Clin. Psychol. Rev., vol. 31, no. 3, pp. 328-341, 2011.

[6] R. Nicole, "Title of paper with only first word capitalized," J. Name Stand. Abbrev, pp. 740-741, 1987.

[7] K. K. S. Voeller, "Attention-deficit hyperactivity disorder (ADHD)," $J$. Child Neurol., vol. 19, no. 10, pp. 798-814, 2004.

[8] E. Ahmann, "Interventions for ADHD in Children And Teens: A Focus on ADHD Coaching.," Pediatr. Nurs., vol. 43, no. 3, pp. 121-131, 2017.

[9] Y. Handoyo, "Autisme pada anak: Menyiapkan anak autis untuk mandiri dan masuk sekolah reguler dengan Metode ABA Basic," Jakarta Bhuana Ilmu Pop, 2009.

[10]M. Young, The technical writer's handbook: writing with style and clarity. University Science Books, 2002.

[11]Y. Aoki et al., "Association of White Matter Structure With Autism Spectrum Disorder and Attention-Deficit/Hyperactivity Disorder," JAMA PSYCHIATRY, vol. 74, no. 11, pp. 1120-1128, 2017.

[12]S. Hartinah, "Konsep Dasar Bimbingan Kelompok," Bandung PT. Refika Aditama, 2009.

[13]A. Yusuf, K. Bahiyah, and I. G. A. Wadmi, "Crossword Puzzle Increase Attention of Children with ADHD," J. Ners, vol. 4, no. 2, pp. 139-143, 2017.

[14]R. Pinzon and L. Asanti, AWAS STROKE! Pengertian, Gejala, Tindakan, Perawatan dan Pencegahan. Penerbit Andi, 2010.

[15]G. R. Elliott et al., "Cognitive testing to identify children with ADHD who do and do not respond to methylphenidate," J. Atten. Disord., p. $1087054714543924,2014$.

[16] M. Mursanib, "Meningkatkan keterampilan Identifikasi Anak Berkebutuhan Khusus Bagi Mahasiswa Prodi. PG/PAUD FKIP Universitas Tadulako," Tri Sentra J. Ilmu Pendidik., vol. 2, no. 4, 2014.

[17]Y. Nakai, T. Takiguchi, G. Matsui, N. Yamaoka, and S. Takada, "Detecting Abnormal Word Utterances in Children With Autism Spectrum Disorders: Machine-Learning-Based Voice Analysis Versus Speech Therapists,” Percept. Mot. Skills, vol. 124, no. 5, pp. 961-973, 2017.
[18]R.-Y. Zhou, J.-J. Wang, J.-C. Sun, Y. You, J.-N. Ying, and X.-M. Han, "Attention deficit hyperactivity disorder may be a highly inflammation and immune-associated disease (Review)," Mol. Med. Rep., vol. 16, no. 4, pp. 5071-5077, 2017.

[19]S. P. ARDIYATI and M. S. MG Adiyanti, "Pelatihan pemahaman ADHD bagi orangtua dan guru untuk meningkatkan kemampuan deteksi dini." Universitas Gadjah Mada, 2015.

[20]R. H. Weisler, "Emerging drugs for attention-deficit/hyperactivity disorder," Expert Opin. Emerg. Drugs, vol. 12, no. 3, pp. 423-434, Sep. 2007.

[21]D. Rusmawati, "Pengaruh Terapi Musik Terhadap Hiperaktivitas Siswa dengan Gangguan ADHD.” Abstrak, 2010.

[22]N. Handayani, "Penerapan Prinsip Operant Conditioning Dalam Mengurangi Perilaku Mengganggu Teman Sebaya Pada Anak ADHD (Attention Deficit Hyperactive Disorder)." University of Muhammadiyah Malang, 2012.

[23]N. Hatiningsih, "Play Therapy untuk Meningkatkan Konsentrasi pada Anak Attention Deficit Hyperactive Disorder (ADHD)," J. Ilm. Psikol. Terap., vol. 1, no. 2, pp. 324-342, 2013.

[24]P. Y. Artanti, "Studi Deskriptif Terapi Terhadap Penderita Autisme pada Anak Usia Dini di Mutia Center Kecamatan Bojong Kabupaten Purbalingga," Indones. J. Early Child. Educ. Stud., vol. 1, no. 1, 2012.

[25]I. E. Drmic, M. Aljunied, and J. Reaven, "Feasibility, Acceptability and Preliminary Treatment Outcomes in a School-Based CBT Intervention Program for Adolescents with ASD and Anxiety in Singapore," J. Autism Dev. Disord., vol. 47, no. 12, SI, pp. 39093929, 2017.

[26] Sunanik, "Pelaksanaan Terapi Wicara dan Terapi Sensori Integrasi pada Anak Terlambat Bicara," J. Pendidik. Islam, vol. 7, no. April, 2013.

[27] B. H. Song, M. Merchant, and L. Schloegel, "Voice Outcomes of Adults Diagnosed with Pediatric Vocal Fold Nodules and Impact of Speech Therapy," Otolaryngol. NECK Surg., vol. 157, no. 5, pp. 824829, 2017.

[28] A. B. Setyawan and B. Psikiatri, "Aspek neurologis attention deficit hyperactivity disorder (ADHD)," J. Ilm. Kedokt. Wijaya Kusuma, vol. 2, pp. 63-82, 2010 .

[29] T. W. Strine et al., "PEER REVIEWED: Emotional and Behavioral Difficulties and Impairments in Everyday Functioning Among Children With a History of Attention-Deficit/Hyperactivity Disorder," Prev. Chronic Dis., vol. 3, no. 2, 2006.

[30] WHO, LEKSIKON Istilah Kesehatan Jiwa \& Psikiatrik (Alih Bahas Tun K. Bastaman, dkk). Jakarta: Buku Kedokteran, 2004.

[31] I. K. Tadris, "Leksikon Istilah Kesehatan Jiwa dan Psikiatri," Jakarta Buku Kedokt. EGD, 2007.

[32] WHO, "LEKSIKON Istilah Kesehatan Jiwa \& Psikiatrik (Alih Bahas Tun K. Bastaman, dkk).” Buku Kedokteran, Jakarta, 2004. 
[33] M. Brunner, E. Kizilkaya, and P. K. Plinkert, "The Influence of Speech and Language Therapy on the Development of Phoneme Discrimination and Dyslexia ,"Spr. Stimme Gehor, vol. 41, no. 3, pp. 154-159, 2017.

[34] A. Morin, "The difference between," no. 1998. 2005.

[35] Y. Handoyo, "Autisme pada anak: Menyiapkan anak autis untuk mandiri dan masuk sekolah reguler dengan Metode ABA Basic," Jakarta Bhuana Ilmu Pop., 2009.
[36] S. Rahayu, "Evaluasi Pelaksanaan Program Terapi Wicara Dalam Meningkatkan Perkembangan Anak Terlantar Di Yayasan Sayap Ibu Kebayoran Baru, Jakarta Selatan,” 2009. 